\title{
Competitive Sorption of Lead and Cadmium (II) Ions from Aqueous Media Using Carbon from Bamboo Culms and Periwinkle Shells
}

\author{
NWORIE*, C.E. MAHMUD H, AKANBI, O. P., OCHI, D.O \\ Chemical Engineering Department, Auchi polytechnic, Auchi, Edo State, Nigeria \\ *Corresponding Author: NWORIE Chemical Engineering Department, Auchi polytechnic, Auchi, Edo \\ State, Nigeria
}

\begin{abstract}
The study assessed the potential application of periwinkle shells and bamboo culms carbon as biosorbents for the competitive sorption of cadmium and lead ions from aqueous solution. The bamboo culms and periwinkle shells were carbonized (pyrolyzed) at 500 ${ }^{\circ}$. These were milled, sieved with shaker sieve and some of the carbon (bamboo and periwinkle) were blended in a rotary blender in the ratio of 1:1. The bamboo and periwinkle carbon were characterized and used to determine the amount absorbed $\left(q^{t}\right) \mathrm{mg} / \mathrm{g}$. The applicability of equilibrium isotherms models and equilibrium kinetics models were examined for the experimental data. The results from the competitive sorption systems shows that sorption maxima $\left(\mathrm{mgg}^{-1}\right)$ for the $\mathrm{Cd}$, and $\mathrm{Pb}$ ions followed the order $\mathrm{Cd}^{2+}>\mathrm{Pb}^{2+}$ for the sorbents. In equilibrium kinetics, the experimental data fits pseudo second order equation.
\end{abstract}

Keywords: Competitive sorption, Carbon, Aqueous media Cadmium, Lead.

\section{INTRODUCTION}

The pollution problem of industrial waste water is becoming negatively of great concern in the world today. Consequently, the treatment of polluted industrial waste water remains a topic of global concern since waste water collected from industries contaminates the ground water and must ultimately be returned to receiving waters or to the land (Mohsen, 2007).

Lead and other heavy metals are one of the major pollutants in the environment and they exhibit a potentially damaging effect on human physiology and other biological systems when the tolerance levels are exceeded (Joshi, 2003).

Metals like lead and cadmium are of special concern because they are not biodegradable and therefore persistent. Their presence in the streams and lakes ranges from beneficial through troublesome to dangerously toxic (ATSDR, 2001). Therefore, elimination of heavy metals from water and waste water is important to protect public health and wildlife (Elachia et.al, 2005).

A number of treatment methods for the removal of heavy metals ions from waste water have been reported in various literatures which include among others, ion exchange, adsorption, etc (Ahmedina et.al, 1997).

Most of these methods suffer from drawbacks such as high capital, operational cost, time consumption, equipment complexity and the disposal of the residual metal sludge (Amuda and Ibrahim, 2006). Adsorption is the process of collecting soluble substances (adsorbate) that are in solution, on a suitable interface (with adsorbent). The interface can be between the liquid and a gas, a solid, or another liquid. Absorption offers the best solution since the process is cheap, fast and fewer complexes coupled with the fact that sophisticated items of equipment are not required to conduct the experiments (ASTM, D4607).

The use of sorbents produced from biomass to remove heavy metals because of its high chemical activity, reliability, low cost and availability has been discussed in several studies (Ahmed et.al, 2011). 
With this in mind, we have sought to explore the potential use of periwinkle shells and bamboo culms carbon as sorbents for the sorption of cadmium and lead ions from aqueous media. Periwinkle shells are a waste product generated from the consumption of periwinkle, a small greenish-blue marine snail found in many coastal communities within Nigeria (Olutoge et.al, 2012). The shells are typically disposed of after consuming the edible parts as sea food thereby contributing to environmental pollution. The reuse capacity of these shells can be improved by utilizing them for the development of value added products such as biosorbents. In the process, the environmental burden posed by their inappropriate disposal is also eliminated.

Bamboo is one of the oldest building materials used by mankind (Abd-Latif, and Abd-Razak, 1991). The bamboo culms, or stem, have been made into an extended diversity of products ranging from domestic household products to industrial applications. Examples of bamboo products are food containers, skewers, chopsticks, handicrafts, toys, furniture's, flooring, pulp and papers, boats, charcoal, musical instruments and weapons. In Asia, bamboo is quite common for bridges, scaffolding and housing, but it is usually a temporary exterior structural material. In many overly populated regions of the tropics, certain bamboos supply the one suitable material that is sufficiently cheap and plentiful to meet the extensive need for economical housing.

In this work, we study the potential application of periwinkle shells and bamboo culms carbon as biosorbents for the competitive sorption of cadmium and lead ions from aqueous solution through:

i. Preparation of periwinkle shells and bamboo culms carbon.

ii. Characterization of the periwinkle shells and bamboo culms carbon produced to determine their physiochemical properties.

iii. Evaluation of the sorption potentials of the carbon for cadmium and lead from aqueous media,

(iv) Evaluation of the adsorption equilibrium isotherm and kinetics using the Langmuir, Freundlich, Temkin and Dubinin-Radushkevich and Largergren pseudo first order, Pseudo second order, Elovich equation and intra-particle diffusion model.

\section{Materials AND MethoD}

\subsection{Materials}

Table 2.1. Materials, reagents source and grade

\begin{tabular}{|l|l|c|}
\hline Materials/Reagents & Supplier/Source & Grade \\
\hline Periwinkle shells & $\begin{array}{l}\text { Sourced locally from Rumolumini by } \\
\text { sliverbird cinema in portharcourt, River } \\
\text { state. (7.01 } \mathrm{E}, 4.78^{0} \mathrm{~N}, 16 \mathrm{~m} \text { above sea } \\
\text { level). }\end{array}$ & - \\
\hline Bamboo culms & $\begin{array}{l}\text { Sourced locally from Igieduma, Benin- } \\
\text { Auchi Road, Ehor, Edo State. (5.37 } \\
6.20^{0} \mathrm{E},\end{array}$ & - \\
\hline $\begin{array}{l}\text { Lead nitrate }\left(\mathrm{Pb}\left(\mathrm{NO}_{3}\right)_{2}, \text { Sodium above sea level. }\right. \\
\text { hydroxide, hydrogen chloride, nitric acid } \\
\text { and cadmium nitrate } \mathrm{Cd}\left(\mathrm{NO}_{3}\right)_{2}\end{array}$ & Sigma Aldrich, Germany & Analar grade \\
\hline Muffle furnace & Green lab, Palm House, Benin City & - \\
\hline $\begin{array}{l}\text { Atomic Absorption } \\
\text { Spectrophotometer(AAS) }\end{array}$ & Integrated Lab at M.M. way, Benin City & - \\
\hline Distilled water & $\begin{array}{l}\text { Purchase from chemical sales outlet in } \\
\text { Igbe road, Auchi }\end{array}$ & - \\
\hline
\end{tabular}

\subsection{Preparation of the Cadmium and Lead Ions in Aqueous Media}

Aqueous standard solutions of $\mathrm{Cd}(\mathrm{II})$ and $\mathrm{Pb}$ (II) were prepared by dissolving an accurately weighed amount of $\mathrm{Cd}\left(\mathrm{NO}_{3}\right)_{2}$ and $\mathrm{Pb}\left(\mathrm{NO}_{3}\right)_{2}$ salts in deionized water so as to yield a metal ion concentration of $1000 \mathrm{mgL}^{-1}$. Appropriate aliquots were taken from these standards for subsequent dilution to the 
desired concentration level. $\mathrm{NaOH}$ and $\mathrm{HCl}$ solutions, both $0.10 \mathrm{molL}^{-1}$, were used for $\mathrm{pH}$ adjustment. $\mathrm{pH}$ meter was used for the $\mathrm{pH}$ measurements. Polyethylene bottles were selected as containers. The bottles were first cleaned with a metal-free non-ionic detergent and washed with tap water. They were then soaked in 1:1 $\mathrm{HNO}_{3}+\mathrm{H}_{2} \mathrm{O}$ solution for $24 \mathrm{~h}$ at $70{ }^{\circ} \mathrm{C}$ and subsequently rinsed thrice with deionized water. The total cadmium and lead concentrations in the solution samples were determined respectively using flame atomic absorption spectroscopy (AAS).

\subsection{Adsorbent preparation and characterization}

The material used in this study was obtained by carbonization of periwinkle shells and bamboo culms respectively in order to prepare the desired biosorbents according to the method described by (Aisien et.al, 2014) with some modification. Thus, it was first washed with detergent solution and then with dilute $\mathrm{HCl}$ in order to remove soil debris. Then the clean and dry parts were taken in a porcelain crucible and carbonized completely at $500{ }^{\circ} \mathrm{C}$ in a muffle furnace for $1 \mathrm{~h}$. The cooled carbon was characterized by standard methods as described by (Ishak and Baker, 1995).

\section{4 pH Determination}

The $\mathrm{pH}$ of the carbonized samples were determined using ASTMD 1512 method, 1983 by immersing $1.0 \mathrm{~g}$ samples in $20.0 \mathrm{ml}$ of deionised water in a $250 \mathrm{ml}$ beaker. The mixture stirred for 15 minutes and the $\mathrm{pH}$ measured using a $\mathrm{pH}$ meter and values were read. Samples were run as triplicates.

\subsection{Bulk Density Determination}

Bulk Density of the carbon was determined by the tampering procedure described by (Ahmedina et.al, 1997). Accurately weighed samples were poured into a uniform cylinder of cross sectional area and were then tapped several times until there was no change in the volume occupied. This volume was then recorded and the bulk density calculated.

\subsection{Determination of Surface Area}

Surface area was measured by adopting the method described by (Ahmedina et.al, 2000). The iodine adsorption method was used in the determination of surface area of the samples. 0.1 molar Sodium Thiosulphate solution was titrated against $20.0 \mathrm{ml}$ of $0.488 \mathrm{M}$ iodine solution containing $0.5 \mathrm{~g}$ of samples using $5.0 \mathrm{ml}$ of freshly prepared Starch solution as indicator. Similarly, the thiosulphate was titrated with $20 \mathrm{ml} 0.488 \mathrm{M}$ iodine solution without samples (blank) and the quantity needed to titrate the blank was determined and procedure carried out in triplicate and the average of the values obtained in each case were calculated and recorded. The surface areas of the powdered samples were calculated using the inverse of the iodine value (I.V).

The iodine adsorption value in chemistry is the mass of iodine in grams that is consumed by 100 grams of a chemical substance, in this case the sample.

Equation: $\mathrm{I}_{2(\text { aq) }}+2 \mathrm{Na}_{2} \mathrm{~S}_{2} \mathrm{O}_{3(\text { aq) }} \rightarrow 2 \mathrm{NaI}_{(\text {aq })}+\mathrm{Na}_{2} \mathrm{~S}_{4} \mathrm{O}_{6(\text { aq })}$

Calculation: The surface area of the RSSC was evaluated using the inverse of the iodine value (I.V.)

$\mathrm{IV}=\mathrm{Y}-\mathrm{X} / \mathrm{y} \times \mathrm{V} / \mathrm{M} \times \mathrm{M}(126.9) \mathrm{mg}$ iodine/100g sample

$\mathrm{Y}=$ Volume of thiosulphate used for blank solution, $\mathrm{M}=$ molarity of iodine solution used.

$\mathrm{X}=$ Volume of thiosulphate used for the RSSC, $\mathrm{W}=$ weight of RSSC used, V = volume of iodine solution used for titration

\subsection{Determination of the Loss on Ignition}

Loss on ignition (LOI) refers to the mass loss of a combustion residue whenever it is heated in an air or oxygen atmosphere to high temperatures. The loss on ignition of the samples was determined gravimetrically, in accordance to the procedure described in ASTM D7348, 1983 and expressed in terms of percentage. Loss on Ignition is a test used in inorganic analytical chemistry, particularly in the analysis of minerals. It consists of strongly heating ("igniting") a sample of the material at a specified temperature, allowing volatile substances to escape, until its mass ceases to change. This may be done in air, or in some other reactive or inert atmosphere. The simple test typically consists of placing a few grams of the material in a tared, pre-ignited crucible and determining its mass, placing it 
in a temperature-controlled furnace for a set time, cooling it in a controlled (e.g. water-free, $\mathrm{CO}_{2}$-free) atmosphere, and predetermining the mass. The process may be repeated to show that mass-change is complete.

\subsection{Determination of the Moisture Content}

The moisture content of the sample was determined by method described in ASTMD 1509, 1983 at $125^{\circ} \mathrm{C}$. This method was used to determine the percentage of water in a 'percentage, by weight, of the dry sample. The moisture sample was determined by weighing the rubber seed shell and record as "wet weight of sample"; the wet sample was dried to a constant weight, at a temperature not exceeding $115^{\circ} \mathrm{C}$ using suitable drying equipment (drying oven). The sample was allowed to cool and then weighed again, and recorded as the "dry weight of sample"

\section{Calculation}

The moisture content of the sample is calculated using the following equation:

$\% \mathrm{~W}=\frac{\mathrm{A}-\mathrm{B}}{1} \times \underline{100}$

Where:

$\% \mathrm{~W}=$ Percentage of moisture in the sample,

$\mathrm{A}=$ Weight of wet sample (grams), and

$\mathrm{B}=$ Weight of dry sample (grams)

\subsection{Determination of the Metal content of the carbon}

The method adopted here for metal content analysis of carbon samples was that used by (Jones, 1990) $1 \mathrm{~g}$ of the sample was weighed and ashed at $510^{\circ} \mathrm{C}, 10 \%$ nitric acid was used to digest the sample and made up to $100 \mathrm{ml}$ mark in a $100 \mathrm{ml}$ volumetric flask. Portions of the sample in the flask were used for the determination of metal contents. For Calcium and Magnesium determination, $10 \mathrm{ml}$ of the aliquot was titrated with 0.004 molar concentration of Ethylenediamminetetra-acetic acid (EDTA) using Erichrome Black T as the indicator, Potassium Cyanide as the masking agent, Ammonia buffer and Hydroxylamine Hydrochloride. For Calcium determination, $10 \mathrm{ml}$ of the aliquot was titrated with 0.004M EDTA, Cal-red was used as indicator, Potassium Cyanide as masking agent, 8M Potassium Hydroxide as buffer. Necessary calculations were done to determine the values of the calcium and Magnesium contents. The Sodium and the Potassium contents were determined using Flame Photometer.

\subsection{Adsorption studies}

Adsorption isotherms were determined using the batch equilibrium method. The adsorption of $\mathrm{Cd}(\mathrm{II})$ and $\mathrm{Pb}(\mathrm{II})$ were studied after adding $5 \mathrm{~g} \mathrm{mg}$ of adsorbent into an aqueous solution containing the desired $\mathrm{Cd}(\mathrm{II})$ and $\mathrm{Pb}$ (II) concentration $\left(50-500 \mathrm{mgL}^{-1}\right)$ respectively, adjusting the $\mathrm{pH}$ of the solution to 6, shaking at $150 \mathrm{rpm}$ for $2 \mathrm{~h}$ at $25{ }^{\circ} \mathrm{C}$ in a reciprocating shaker and then the samples were centrifuged at $5000 \mathrm{rpm}$ for $5 \mathrm{~min}$. The adsorbent particles were separated from the suspensions by filtration through a $75 \mu \mathrm{m}$ membrane filter. The residual concentrations of cadmium and lead ions were determined by atomic absorption spectrometry.

In addition to the adsorption tests, a set of blank tests with adsorbent was conducted in order to evaluate the removal by metal hydroxide precipitation at the $\mathrm{pH}$ of determination. The amount of $\mathrm{Cd}$ (II) and $\mathrm{Pb}$ (II) adsorbed on the adsorbents were calculated from the difference between the initial concentration and the equilibrium concentration of $\mathrm{Cd}$ (II) and $\mathrm{Pb}$ (II). The percent $\mathrm{Cd}$ (II) and $\mathrm{Pb}$ (II) removal, $R \mathrm{e}$, was calculated using the following equation:

$$
\operatorname{Re}=\underline{\left(\mathrm{C}_{\mathrm{i}}-\mathrm{C}_{\mathrm{f}}\right) \times \underline{100}}
$$

where $C_{\mathrm{i}}$ and $C_{\mathrm{f}}$ are the initial and equilibrium concentrations of the adsorbate, respectively.

The reported value of $\mathrm{Cd}(\mathrm{II})$ and $\mathrm{Pb}$ (II) ions adsorbed by adsorbent in each test was the average of at least three measurements. 


\subsection{Batch mode adsorption studies}

Batch mode adsorption studies for individual metal compounds were carried out to investigate the effect of adsorbate concentration. Solution containing adsorbate and adsorbent was taken in $250 \mathrm{~mL}$ capacity beakers and agitated at $150 \mathrm{rpm}$ in a mechanical shaker at predetermined time intervals. The adsorbate was decanted and separated from the adsorbent using Whatman No.1 filter paper. To avoid the adsorption of adsorbate on the container walls, the containers were pretreated with the respective adsorbate for 24 hours.

\subsection{Desorption studies}

After adsorption, the adsorbates - loaded adsorbent were separated from the solution by centrifugation and the supernatant was drained out. The adsorbent was gently washed with water to remove any unadsorbed adsorbate. Regeneration of adsorbate from the adsorbate - laden adsorbent was carried out using the desorbing media - distilled water at $\mathrm{pH}$ ranges 4.0 to 12.0 using dilute solutions of $\mathrm{NaOH}$ and $\mathrm{HCl}$. Then they were agitated for the equilibrium time of respective adsorbate. The desorbed adsorbate in the solution was separated and analyzed for the residual heavy metals.

\section{RESULTS AND DISCUSSIONS}

\subsection{Characteristics of Bamboo culms carbon}

Table 3.1. The characteristics of the powdered carbon prepared from Bamboo culms

\begin{tabular}{lccccc}
$\begin{array}{l}\text { Ash Content } \\
(\%)\end{array}$ & $\mathbf{p H}$ & $\begin{array}{l}\text { Bulk Density } \\
\left(\mathbf{g} / \mathbf{c m}^{\mathbf{3}}\right)\end{array}$ & $\begin{array}{c}\text { Surface Area } \\
\mathbf{1 0}^{\mathbf{2}}\left(\mathbf{g} / \mathbf{m g I}_{\mathbf{2}}\right)\end{array}$ & $\begin{array}{c}\text { Moisture Content } \\
(\boldsymbol{\%})\end{array}$ & $\begin{array}{c}\text { Particle size } \\
\boldsymbol{\mu m}\end{array}$ \\
\hline $3.91 \pm 0.02$ & $7.8 \pm 0.01$ & $0.499 \pm 0.01$ & $0.126 \pm 0.15$ & $4.98 \pm 0.01$ & $75 \pm 0.00$ \\
\hline
\end{tabular}

The values of the $\mathrm{pH}$ of bamboo culms carbon are within the range of 6-8 which is the normal range for sorption by carbon because of the tendency towards alkalinity of the $\mathrm{pH}$ of 7.8. This signifies that the surface charges are negative, which shows an attraction towards heavy metals.

\subsection{Characterization of Periwinkle shell carbon}

Table 3.2. The characteristics of the powdered carbon prepared from periwinkle shells.

\begin{tabular}{lccccc}
\hline $\begin{array}{l}\text { Ash Content } \\
(\mathbf{\%})\end{array}$ & $\mathbf{p H}$ & $\begin{array}{c}\text { Bulk Density } \\
\left(\mathbf{g} / \mathbf{c m}^{\mathbf{3}}\right)\end{array}$ & $\begin{array}{c}\text { Surface Area } \\
\mathbf{1 0}^{\mathbf{2}}\left(\mathbf{g} / \mathbf{m g I}_{\mathbf{2}}\right)\end{array}$ & $\begin{array}{c}\text { Moisture Content } \\
(\boldsymbol{\%})\end{array}$ & $\begin{array}{c}\text { Particle size } \\
\boldsymbol{\mu m}\end{array}$ \\
\hline $4.58 \pm 0.02$ & $6.8 \pm 0.01$ & $0.148 \pm 0.01$ & $0.086 \pm 0.15$ & $10.01 \pm 0.01$ & $75 \pm 0.00$ \\
\hline
\end{tabular}

The value of the $\mathrm{pH} 6.8$ obtained from periwinkle shells carbon is near neutrality which is within the range of sorption of heavy metals by carbon.

Table 3.4. Isotherm Constants of four Isotherm Models for the competitive sorption of $\mathrm{Cd}^{2+}$ and $\mathrm{Pb}^{2+}$ by Biosorbents. $\left(C_{0}=2.0-50.0 \mathrm{mg} / \mathrm{l}\right.$ for $\mathrm{Pb}^{2+}$ and $\mathrm{Cd}^{2+}$, Dosage $\left.=0.5 \mathrm{~g}, \mathrm{~T}=25^{\circ \mathrm{C}}, t=3 \mathrm{hr}\right)$

\begin{tabular}{|l|l|l|l|}
\hline Isotherm Model & Constants & \multicolumn{1}{|c|}{$\mathbf{P b}^{2+}$} & \multicolumn{1}{|c|}{$\mathbf{C d}^{2+}$} \\
\hline & & PSC, BCC, BPCB & PSC, BCC, BPCB \\
\hline Langmuir Isotherm & $\mathrm{q}_{\max }(\mathrm{mg} / \mathrm{g})$ & $0.95,0.97,0.98$ & $0.95,1.00,1.00$ \\
& $\mathrm{~K}_{\mathrm{L}} \times 10^{-3}(\mathrm{~L} / \mathrm{mg})$ & $267.00,450.70,159.70$ & $557.10,750.90,255.00$ \\
& $\mathrm{R}^{2}$ & $0.910,0.220,0.660$ & $0.820,0.380,0.590$ \\
\hline Freundlich Isotherm & $\mathrm{K}_{\mathrm{f}}$ & $1.44,1.01,1.14$ & $1.31,1.02,1.08$ \\
& $\mathrm{n}$ & $1.01,1.02,1.08$ & $1.01,1.01,1.05$ \\
& $\mathrm{R}^{2}$ & $0.998,0.997,0.999$ & $0.990,0.999,0.999$ \\
\hline Temkin Isotherm & $\mathrm{B}_{1}$ & $20.94,20.67,19.62$ & $22.23,22.27,17.64$ \\
& $\mathrm{~b}$ & $118.4,120.0,126.30$ & $111.50,111.30,140.50$ \\
& $\mathrm{~K}_{\mathrm{t}}$ & $7.96, \quad 6.96,6.78$ & $7.90,7.16,6.56$ \\
& $\mathrm{R}^{2}$ & $0.990,0.980,0.970$ & $0.970,0.970,0.960$ \\
\hline Dubinin & $\mathrm{K}_{\mathrm{ad}} \times 10^{-5}$ & $284,280,255$ & $285,261,247$ \\
Radushkevich & $\mathrm{q}_{\mathrm{s}}$ & $0.980,0.980,0.820$ & $33.80,26.30,22.80$ \\
& $\mathrm{R}^{2}$ & \multicolumn{2}{|c|}{$0.980,0.820,0.820$} \\
\hline
\end{tabular}


Four models (Langmuir, Freundlich, Temkin and Dubinin-Radushkevich) were used. Frenudlich isotherm equal fits the data based on the correlation coefficients for all the sorption process.

From the variable qMax, the blended bamboo and periwinkle shells is higher compared to other sorbents for $\mathrm{Pb}^{2+}$ while also the blended bamboo and periwinkle shells and bamboo culms carbon are higher for $\mathrm{Cd}^{2+}$ sorption. Based on qMax the $\mathrm{Cd}^{2+}$ is preferable to $\mathrm{Pb}^{2+}$ in sorption because of atomic radius or size of the $\mathrm{Cd}^{2+}$ compared to $\mathrm{Pb}^{2+}$.

Table 3.6. Kinetic Parameters of the Kinetic Models for the Competitive Sorption of $\mathrm{Pb}^{2+}$ and $\mathrm{Cd}^{2+}(T=298 \mathrm{~K}$, Initial $\mathrm{pH}=7$, Dosage $=0.5 \mathrm{~g} / 100 \mathrm{ml}, \mathrm{Ce}=20 \mathrm{mg} / \mathrm{l})$

\begin{tabular}{|c|c|c|c|}
\hline Kinetics Model & Constants & $\begin{array}{l}\mathbf{P b}^{2+} \\
\mathbf{P S C}, \mathbf{B C C}, \mathbf{B P C B}\end{array}$ & $\begin{array}{l}\mathrm{Cd}^{2+} \\
\mathrm{PSC}, \mathrm{BCC}, \mathrm{BPCB}\end{array}$ \\
\hline $\begin{array}{l}\text { Pseudo first } \\
\text { order }\end{array}$ & $\begin{array}{l}\mathrm{q}_{\mathrm{e}} \text { calc. }(\mathrm{mg} / \mathrm{g}) \\
\mathrm{K}_{1} \\
\mathrm{R}^{2}\end{array}$ & $\begin{array}{l}2.64,1.37,1.22 \\
0.02,0.10,0.12 \\
0.999,0.540,0.760\end{array}$ & $\begin{array}{l}3.29,1.92,1.76 \\
0.23,0.15,0.20 \\
0.99,0.79,0.800\end{array}$ \\
\hline $\begin{array}{l}\text { Pseudo Second } \\
\text { order }\end{array}$ & $\begin{array}{l}\mathrm{q}_{\mathrm{e}} \text { calc } \\
\mathrm{K}_{2} \\
\mathrm{R}^{2}\end{array}$ & $\begin{array}{l}9.02,8.50,9.24 \\
0.43,3.00,0.91 \\
0.999,0.999,0.999\end{array}$ & $\begin{array}{l}9.76,9.51,9.77 \\
0.30,0.67,1.66 \\
0.999,0.999, .999\end{array}$ \\
\hline $\begin{array}{l}\text { Elovich } \\
\text { Equation }\end{array}$ & $\begin{array}{ll}\alpha(\mathrm{mmol} / \mathrm{g}) \quad \mathrm{x} \\
10^{5} \\
\beta(\mathrm{g} / \mathrm{mmol}) \\
\mathrm{R}^{2} \\
\end{array}$ & $\begin{array}{l}0.91,0.52,0.47 \\
2635.8,1642264.8,39751696.9 \\
0.810,0.810,0.730\end{array}$ & $\begin{array}{l}0.94,0.75,0.63 \\
2420.4,46678.2,531156.2 \\
0.900,0.770,0.910\end{array}$ \\
\hline $\begin{array}{l}\text { Intraparticle } \\
\text { Diffusion model }\end{array}$ & $\begin{array}{l}\text { Kid } \quad\left(\mathrm{mg} / \mathrm{gin}^{-}\right. \\
\text {Intercept } \\
\mathrm{R}^{2}\end{array}$ & \begin{tabular}{|l|}
$0.93,0.54,0.58$ \\
$6.02,7.00,7.49$ \\
$0.830,0.630,0.750$
\end{tabular} & $\begin{array}{l}1.07,0.77,0.67 \\
6.23,7.16,7.67 \\
0.860,0.740,0.750\end{array}$ \\
\hline
\end{tabular}

Four models were used to determine the mass of the metals per unit time. The study shows that pseudo second order fits the data most based on the correlation coefficients which shows that the rate of sorption of the metals is second order reaction.

\section{CONClusion}

It has been shown that blended bamboo culms carbon and periwinkle shell carbon were successfully prepared with significant characteristics which make them suitable for use in sorption of lead and cadmium ions in aqueous media. The carbon produced for metal ions removal was technically feasible, eco-friendly and with high efficiency.

\section{REFERENCES}

Mohsen, A.H, (2007): Adsorption of lead ions from aqueous solution by okra waste, International Journal of Physical Sciences, 2(7), pp.178-184.

Joshi, N., (2003): Biosorption of heavy metals, M.Sc thesis, Department of Biotechnology and Environmental sciences Thapar Institute of Engineering and Technology.

ATSDR, (2001) "Toxicological profile for copper: US Dept of Health and Human services, public health services.

Elachia, M., Mendez, P., Havel, J. and Patocka J., (2005): Humic Substances compounds of still unknown structure: Applications in Agriculture, Industry, Environment and Biomedicine, J. Appl. Biomed, 3, pp. $13-24$.

Ahmedina, M., Johns, M.M., Clarke, S.J,. Marshall,W.E. and Rao, R.M. (1997): potential of Agricultural by product based activated carbons for use in raw sugar decolorization, Journal of agriculture and food science, $75: 117-124$.

Amuda, O.S and A.O Ibrahim, (2006): Industrial waste water treatment using natural material as adsorbent, African Journal of Biotechnology, 5(16): 23-39. 
Ahmedna, M. Marshal, W. E. and Rao, M. R. (2000): Granular activated carbons from agricultural by products; preparation, properties and application in cane sugar refining. Bulletin of Lousiana State University Agricultural centre

Olutoge, Festus A., Oriyomi M. Okeyinka and Olatunji S. Olamyan, (2012): Assessment of the suitability of periwinkle shell ash (PSA) as partial replacement for ordinary portland cement (opc) in concrete. "IJRRAS, vol.10 iss.3, pp. 428-434.54 app.

Aisien, F.A., Amenaghawon, N.A. and Otuorimuo, U.O. (2014): Decolourisation of methylene blue in aqueous solution using locally sourced photocatalysts via UV irradiation photocatlytic degradation. Moroccan Journal of Chemistry, 2(4): 320-329.

Ahmed, M. E., El-zekky, D. A., Aiad, K. M., Shedata, E. I. (2011): Influence of organic matter in the adsorption of sodium. Jour. Of soil science and Envi. Management. Vol. 3(1) P 23-27.

Abd - Latif M. and Abd-Razak, O. (1991). Availability, distribution k of

bamboo and its Industrial status in peninsular Malaysia. Proceedings of $4^{\text {th }}$ international Bamboo Workshop. Bamboo in Asia and the pacific driangma, Thailand 60-67.

Ishak, A.A. and Baker, N. (1995): An investigation on the potential of rice husk ash as fillers for epoxidized natural rubber. Eur. Polym., 31 (3) (1995), pp. 259-26.

Jones, J.B. Jr. (1990): Universal soil extract ants; their composition and use. Commun.Soil Sci. Plant Anal. 21: 1091-1101.

ASTM, D4607-94: Standard method for the determination of iodine number of activated carbon.

ASTMD 1512, (1983): Standard method of testing for $\mathrm{pH}$.

ASTMD 7348, (1983): Standard methods for Loss on Ignition (LOI) of solid combustion residues.

ASTMD 1509, (1983): ASTM D 1509 Standard - Standard Test Methods for Carbon black \&\#x2014; Heating Loss.

Citation: NWORI et al., " Competitive Sorption of Lead and Cadmium (II) Ions from Aqueous Media Using Carbon from Bamboo Culms and Periwinkle Shells ", International Journal of Research in Environmental Science, vol. 3, no. 4, p. 1-7, 2017. http://dx.doi.org/10.20431/2454-9444.0304001

Copyright: (C) 2017 Authors. This is an open-access article distributed under the terms of the Creative Commons Attribution License, which permits unrestricted use, distribution, and reproduction in any medium, provided the original author and source are credited. 